\title{
Aspen and white spruce productivity is reduced by organic matter removal and soil compaction
}

\author{
by Richard Kabzems ${ }^{1}$
}

\begin{abstract}
Declines in forest productivity have been linked to losses of organic matter and soil porosity. To assess how removal of organic matter and soil compaction affect short-term ecosystem dynamics, pre-treatment and year 1,5 and 10 post-treatment soil properties and post-treatment plant community responses were examined in a boreal trembling aspen (Populus tremuloides Michx.)-dominated ecosystem in northeastern British Columbia. The experiment used a completely randomized design with three levels of organic matter removal (tree stems only; stems and slash; stems, slash and forest floor) and three levels of soil compaction (none, intermediate [2-cm impression], heavy [5-cm impression]). Removal of the forest floor initially stimulated aspen regeneration and significantly reduced height growth of aspen $(198 \mathrm{~cm}$ compared to $472-480 \mathrm{~cm}$ ) as well as white spruce (Picea glauca [Moench] Voss) height $(82 \mathrm{~cm}$ compared to $154-156 \mathrm{~cm})$. The compaction treatments had no effect on aspen regeneration density. At Year 10, heights of both aspen and white spruce were negatively correlated with upper mineral soil bulk density and were lowest on forest floor + whole tree removal treatments. Recovery of soil properties was occurring in the $0 \mathrm{~cm}$ to $2 \mathrm{~cm}$ layer of mineral soil. Bulk density values for the $0 \mathrm{~cm}$ to $10 \mathrm{~cm}$ depth remained above $86 \%$ of the maximum bulk density for the site, a soil condition where reduced tree growth can be expected.
\end{abstract}

Key words: long-term site productivity, boreal forest, Calamagrostis, site index

\section{RÉSUMÉ}

La diminution de la productivité forestière a été associée aux réductions de la matière organique et de la porosité du sol. Dans le but dévaluer comment l'enlèvement de la matière organique et la compaction du sol affectent la dynamique de lécosystème à court terme, les propriétés pédologiques et les réactions de lensemble des plantes avant traitement et un an, cinq ans et dix ans après traitement ont été étudiées dans le cas d'un écosystème dominé par le peuplier faux-tremble (Populus tremuloides Michx.) dans le nord-est de la Colombie-Britannique. Une conception totalement randomisée a été utilisée pour cette étude de l’enlèvement selon trois niveaux de la matière organique (tiges seulement; tiges et rémanents; tiges, rémanents et parterre forestier) et selon trois niveaux de compactage (aucun, intermédiaire [compactage de $2 \mathrm{~cm}$ ], prononcé [compactage de $5 \mathrm{~cm}$ ]. L'enlèvement du parterre forestier a initialement stimulé la régénération du tremble et significativement réduit la croissance en hauteur du tremble $(198 \mathrm{~cm}$ comparativement à 472-480 cm) ainsi que dans le cas de lépinette blanche (Picea glauca [Moench] Voss) $(82 \mathrm{~cm}$ comparativement à 154-156 cm). Les essais de compactage nont eu aucun effet sur la densité de la régénération du tremble. À la dixième année, la hauteur des trembles et des épinettes étaient négativement corrélées à la masse volumique apparente de l'horizon minéral supérieur du sol et était la plus faible dans le cas des traitements où le parterre forestier et l'arbre en entier avaient été extraits. Le rétablissement des propriétés pédologiques sest opéré dans la strate de $0 \mathrm{~cm}$ à $2 \mathrm{~cm}$ du sol minéral. Les valeurs de masse volumique apparente pour la strate de $0 \mathrm{~cm}$ à $10 \mathrm{~cm}$ de profondeur sont demeurées à plus de $86 \%$ de la masse volumique maximale du site, un état pédologique pour lequel on peut sattendre à une réduction de la croissance des arbres.

Mots clés : productivité à long terme d'une station, forêt boréale, Calamagrostis, indice de station

\section{Introduction}

There has been a dramatic expansion in harvesting activity in the western boreal forest since the early 1980s primarily because of the commercial utilization of aspen (David et al. 2001). Aspen (Populus tremuloides Michx.) regeneration is particularly sensitive to soil disturbances such as compaction and rutting during harvesting (Stone and Elioff 1998. Frey et al. 2003, Kabzems and Haeussler 2005, Mundell et al. 2008). Post-harvest gaps in aspen regeneration from all sources can have a combined area of up to $22 \%$ of the original stand (MacIsaac et al. 2006). The reduction of severe soil disturbance and compaction during forest management activities is a key mechanism

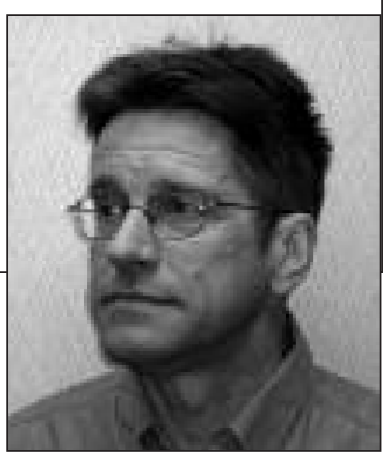

Richard Kabzems to achieve long-term sustainability in boreal forests (Arnup 2000, Sutherland 2003) and to better emulate natural disturbances (Berger et al. 2004). Organic matter losses and decreased aeration porosity resulting from soil compaction

\footnotetext{
${ }^{1}$ British Columbia Ministry of Forests, Lands and Natural Resource Operations, $9000-17^{\text {th }}$ Street, Dawson Creek, British Columbia V1G 4A4. E-mail: Richard.Kabzems@gov.bc.ca
} 
are considered two primary factors contributing to observed declines in forest productivity (Powers et al. 1990).

Soil compaction from logging equipment has long been recognized as an important threat to sustained aspen productivity (Zasada and Tappeiner 1969, Bates et al. 1990, Shepperd 1993, Navratil 1996) particularly in soils with finer textures and imperfect drainage. The medium- to fine-textured soils common to western boreal aspen ecosystems (Beckingham et al. 1996, DeLong et al. 2011) have low strength when wet and slow drainage when saturated (McNabb et al. 2001). Machine traffic during wet conditions causes loss of macropores, results in decreased gas exchange and impedes internal soil drainage (McNabb et al. 2001, Startsev and McNabb 2009). If the saturation period is prolonged, soil warming is slowed and soil aeration reduced.

In contrast to the body of knowledge regarding effects of soil compaction on aspen, there are relatively few studies that examine responses of white spruce (Picea glauca [Moench] Voss) to soil compaction. White spruce seedlings had significant growth reductions when grown on compacted soils in the laboratory (Corns 1988). Competitive vegetation can be more important than soil physical characteristics for early spruce growth (Brais 2001, MacAdam and Kabzems 2006). Twenty-year white spruce volume growth was equivalent between vegetation control alone and the top three mechanical site preparation treatments, which had decreased soil density and improved nutrient availability on boreal sites (Boateng et al. 2009).

This study describes the 10-year response of aspen and white spruce regeneration to organic matter removal and soil compaction treatments and to changes in soil properties (mineral soil bulk density, total carbon concentration, and aeration porosity) in a boreal aspen ecosystem in northeastern British Columbia. It was hypothesized that both aspen and white spruce would show growth reductions in response to the severity of organic matter removal. For soil compaction it was hypothesized that both aspen and white spruce would show a reduction in growth in response to the degree of soil compaction, and that compaction would also reduce the density of aspen regeneration.

\section{Materials and Methods}

The study is located $24 \mathrm{~km}$ north of Dawson Creek (lat. $55^{\circ} 58^{\prime} \mathrm{N}$, long. $120^{\circ} 28^{\prime} \mathrm{W}$, elev. $720 \mathrm{~m}$ ), in the Boreal White and Black Spruce biogeoclimatic zone (BWBSmw subzone; DeLong et al. 2011) of northeastern British Columbia. The even-aged stand of trembling aspen was approximately 100 years old at the start of the study. Slopes average $4 \%$ with a slight south aspect. Soils are classified as Orthic Luvic Gleysols (Soil Classification Working Group 1998) formed on glaciofluvial veneers over glacial till. Coarse fragment contents were less than $5 \%$, and soil textures were $20 \mathrm{~cm}$ to $30 \mathrm{~cm}$ of silt loam over clay loam. Soil moisture regime was mesic; however, the soils were only moderately well drained due to clay-enriched B horizons. The pre-logging forest floor averaged $7 \mathrm{~cm}$ in thickness.

The study is part of the Long Term Soil Productivity (LTSP) program (Powers et al. 1990) and used the LTSP design of a $3 \times 3$ factorial completely randomized design with three replications implemented between 1994 and 1999. Treatment plots measuring $40 \mathrm{~m} \times 70 \mathrm{~m}$ were delineated prior to logging and randomly assigned to one of nine combinations of organic matter removal and soil compaction. The organic matter treatments were: OM1) Stem-only harvest, with a mean of 400 tonnes/ha (fresh weight) of merchantable tree boles removed; OM2) Whole-tree harvest, with a mean of 437 tonnes/ha of merchantable boles and logging slash removed; and $\mathrm{OM}^{3}$ ) Whole-tree harvest + forest floor removal, with a mean of 502 tonnes/ha of merchantable tree boles, logging slash and LFH material removed. Stem and slash removal used a combination of an excavator located outside the plot with manual removal of remaining debris. Forest floor was removed with a large bucket mounted on an excavator that scalped to the organic-mineral soil surface. The soil compaction treatments were: $\mathrm{C} 0$ ) no deliberate compaction; C1) intermediate compaction (2 cm impression in mineral soil); C2) heavy compaction (5 $\mathrm{cm}$ impression in mineral soil) implemented with a vibrating tamping pad mounted on an excavator.

Logging was done in January and February with approximately $15 \mathrm{~cm}$ of ground frost present and minimal machine traffic to avoid soil disturbance. The organic matter and compaction treatments were done the following May, prior to emergence of aspen suckers, but with soils dry enough to prevent churning or rutting by machinery. Less than three weeks after application of the soil disturbance treatments, one randomly selected half of each plot was planted to containergrown $(1+0415 \mathrm{~B}$ styroblock) white spruce seedlings at $2.5 \times$ $2.5 \mathrm{~m}$ spacing. Competing vegetation was manually cut in a $1.25-\mathrm{m}$ radius around each white spruce seedling in each of the first four years after planting. The other half of the plot was allowed to regenerate naturally to trembling aspen. Additional details can be found in Kabzems and Haeussler (2005) and Haeussler and Kabzems (2005).

\section{Soil sampling}

Soils were sampled prior to logging and 1, 5 and 10 years after treatment. For chemical analysis, five (1994 sampling) or six (all other sampling years) composite samples were collected from the forest floor and $0 \mathrm{~cm}$ to 10 and $10 \mathrm{~cm}$ to $20 \mathrm{~cm} \mathrm{min-}$ eral soil layers in each plot. Each composite sample consisted of five randomly selected subsamples. All chemical samples were oven-dried at $70^{\circ} \mathrm{C}$. Mineral soil samples were crushed and sieved through a $2-\mathrm{mm}$ mesh prior to analysis. Total Carbon (C) was determined by dry combustion using a Carlo Erba NA-1500 elemental analyzer (Fisons Instruments, Milan, Italy). A complete description of all chemical analysis methods is provided in Kabzems and Haeussler (2005).

For soil bulk density determination at each sample date, 10 randomly located core samples $\left(500 \mathrm{~cm}^{3}\right)$ were collected from the $0 \mathrm{~cm}$ to $10 \mathrm{~cm}$ ("upper") and $10 \mathrm{~cm}$ to $20 \mathrm{~cm}$ ("lower") mineral soil layers in each plot. The mineral soil bulk density samples were passed through a 2-mm sieve to remove coarse fragments and roots then oven-dried at $105^{\circ} \mathrm{C}$ for 24 hours (Blake and Hartge 1986). Total sample mass, mass and volume of coarse fragments and volume of large roots were determined. Fine fraction bulk density was calculated as the total mass of materials $<2 \mathrm{~mm}$ in diameter, divided by the volume occupied by the $<2 \mathrm{~mm}$ fraction. To determine air-filled porosity at $-10 \mathrm{~J} \cdot \mathrm{kg}^{-1}$ (hereafter, air-filled porosity) at each sample date, five randomly located samples were taken at 0 $\mathrm{cm}$ and $10 \mathrm{~cm}$ mineral soil depths in each plot. Metal cores 
(55 $\mathrm{cm}^{3}, 2 \mathrm{~cm}$ in length) were tamped in to the appropriate depth, and then excavated. Laboratory methods to determine air-filled porosity from intact soil cores followed Campbell (1974) and Klute (1986). This measure of soil porosity represents the difference between the total volume of soil pores expressed as a percentage of the soil sample and the volume of water-filled pores at a tension of $-10 \mathrm{Jkg}^{-1}$ (assumed to be field capacity).

\section{Aspen, white spruce, and vegetation measurements}

Density and height of aspen stems and associated species were measured on at least three randomly selected $50-\mathrm{m}^{2}$ subplots per plot in September and October. The same three aspen subplots were used for assessments each year. Beginning in the second year of the study, an additional measure of aspen height was taken by recording the height of four dominant aspen per $50-\mathrm{m}^{2}$ subplot (one stem in each quarter of the subplot). For white spruce, 100 trees in each spruce half plot were tagged shortly after planting. Total height, height increment, diameter at ground level, total height to diameter at ground level ratio, damage type and damage cause for all sample spruce were recorded at each measurement period. Regeneration assessments were completed for all 27 plots in Years 1, 2, 4, 5 and 10 of the study. Vegetation measurements are described in Haeussler and Kabzems (2005) and were completed for all 27 plots in Years 4, 7, and 10 of the study.

\section{Data analysis}

SYSTAT version 11 (SPSS Inc. 2004) was used for repeated measures ANOVA or ANCOVA and linear regression. Where main effects or interactions had $p$ values $\leq 0.10$, the set of orthogonal contrasts listed in Table 1 was used to differentiate among treatments. Where main effects had $p$ values $\leq 0.10$, planned contrasts that pooled similar main effects (e.g., degree of compaction treatment versus no compaction) were used. A similar approach was used for other soil and

Table 1. Effects of organic matter $(\mathrm{OM})$ removal and soil compaction (C) on total carbon concentration for upper mineral soil [0-10 cm depth]

(a) Total carbon concentration

Total carbon $\left(\mathrm{gkg}^{-1}\right)$

\begin{tabular}{lcccc}
\cline { 2 - 4 } Treatment & Pre-harvest & Year 1 & Year 5 & Year 10 \\
\hline OM1 & 1.13 & 1.67 & 2.14 & 3.16 \\
OM2 & 2.34 & 2.24 & 1.12 & 2.44 \\
OM3 & 1.69 & 1.09 & 2.12 & 1.39 \\
C0 & 2.01 & 1.78 & 1.95 & 1.82 \\
C1 & 1.41 & 1.38 & 2.35 & 1.96 \\
C2 & 1.62 & 1.84 & 1.75
\end{tabular}

(b) Results of the RMANOVA between subjects and within subjects (time)

\begin{tabular}{|c|c|c|c|c|}
\hline Source of variation & df & SS & $\mathbf{F}$ & $P$ value \\
\hline Covariate (1995 harvest) & & & 0.004 & 0.953 \\
\hline Pre-treatment total carbon & 1 & 0.555 & 14.306 & 0.002 \\
\hline OM removal & 2 & 2.672 & 34.460 & 0.000 \\
\hline $\mathrm{C}$ & 2 & 0.054 & 0.695 & 0.514 \\
\hline $\mathrm{OM} \times \mathrm{C}$ & 4 & 0.278 & 1.790 & 0.180 \\
\hline Error & 16 & 0.620 & & \\
\hline Year & 2 & 0.010 & 0.185 & 0.832 \\
\hline Year $\times$ OM removal & 4 & 0.246 & 2.297 & 0.081 \\
\hline Year $\times C$ & 4 & 0.197 & 1.835 & 0.146 \\
\hline Year $\times$ OM removal $\times \mathrm{C}$ & 8 & 0.082 & 0.384 & 0.921 \\
\hline Year $\times$ Pre-treatment total carbon & 2 & 0.031 & 0.572 & 0.570 \\
\hline Error & 32 & 0.857 & & \\
\hline \multicolumn{5}{|l|}{ Contrasts } \\
\hline OM1 vs. OM2 Year 1 & 1 & 0.044 & 1.861 & 0.191 \\
\hline OM1 vs. OM2 Year 5 & 1 & 0.055 & 1.405 & 0.253 \\
\hline OM1 vs. OM2 Year 10 & 1 & 0.034 & 1.12 & 0.306 \\
\hline OM1/OM2 vs. OM3 Year 1 & 1 & 0.742 & 31.630 & 0.000 \\
\hline OM1/OM2 vs. OM3 Year 5 & 1 & 1.727 & 44.312 & 0.000 \\
\hline OM1/OM2 vs. OM3 Year 10 & 1 & 0.389 & 13.004 & 0.002 \\
\hline
\end{tabular}

Note: OM1, stems only; OM2, stems and slash; OM3 stems, slash and forest floor; C0, no compaction; C1, moderate compaction; C2, heavy compaction. P values were considered significant at $p<0.1$ (shown in bold) as determined by repeated measures ANOVA and planned contrasts. The covariate 1995 logging was nonsignificant, remaining results are for analysis without covariate. Data were square-root transformed, and pre-treatment total carbon was used as a covariate. 
tree properties. To reduce the likelihood of type II errors, all tests were considered significant at $\alpha=0.10$, except where otherwise noted. A univariate ANOVA was carried out to determine whether there were significant pre-treatment differences in soil properties. There was no evidence of pre-harvest differences for most parameters. Indicator variables for the year of treatment were introduced as covariates in all post-treatment models. Where appropriate, data were transformed to improve assumptions of normality and equality of variances among treatment groups. Aspen site index was determined from equations of Nigh et al. (2002).

Multiple linear regression was used to examine relationships between post-treatment aspen height, white spruce height, and bluejoint (Calamagrostis canadensis L.) cover and various indices of soil chemical properties, airfilled porosity, and bulk density. Organic matter removal treatments and year of harvest were used as indicator variables and dummy interaction terms in the regression (Neter et al. 1983).

\section{Results}

Interactions between organic matter removal and soil compaction were not significant at the Year 10 analysis for the majority of soil properties and tree growth responses. The main experimental factors of organic removal and soil compaction can be discussed separately except where noted. The effect of organic matter removal changed significantly $(p<0.081)$ over the 10-year measurement period (Table $1)$. Covariance analysis indicated that the year of treatment did not significantly $(p<0.953)$ influence soil properties at the Year 10 analysis (Table 1).

Ten years after treatment, total C concentration in the upper mineral soil was significantly lower after forest floor + whole tree removal than after stem or stem and slash removal (Table 1). Total C concentrations in the forest floor + whole tree removal treatment had increased between years 1 and 10 but were still below pre-harvest levels (Table 1).

The scalping technique used to remove the forest floor also increased upper mineral soil bulk density (Fig. 1). Where forest floors were removed, mineral soil bulk density at $0 \mathrm{~cm}$ to $10 \mathrm{~cm}$ was $26 \%$ higher in Year 10 , compared with pre-harvest conditions. Air-filled porosity at $0 \mathrm{~cm}$ to $2 \mathrm{~cm}$ in the mineral soil of the OM3 treatment had increased from $11 \mathrm{~m}^{3} \mathrm{~m}^{-3}$ in Year 1 to $14 \mathrm{~m}^{3} \mathrm{~m}^{-3}$ by Year 10 , which was still below the pre-harvest average of $20 \mathrm{~m}^{3} \mathrm{~m}^{-3}$.

Ten years post treatment; the uncompacted soils had the lowest bulk density in the upper $10 \mathrm{~cm}$ of mineral soil, significantly lower than both heavy and intermediate compaction treatments (Fig. 2). Compared to pre-harvest bulk density, the uncompacted soils were $0.5 \%$ greater at Year 10 , while the

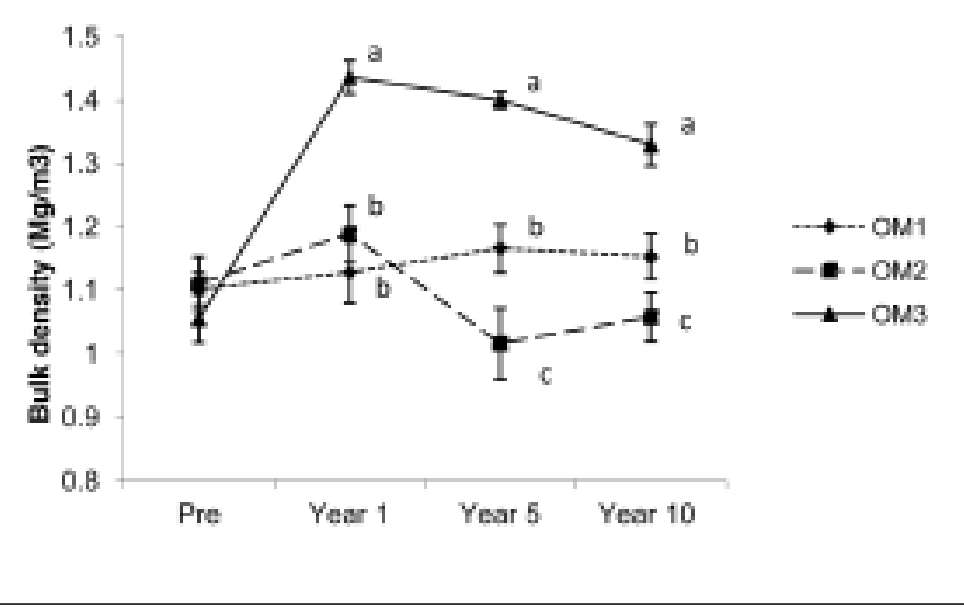

Fig. 1. Upper $(0-10 \mathrm{~cm})$ mineral soil bulk density by organic matter removal treatment (OM1, stems only; OM2, stems and slash; OM3, stems, slash, and forest floor]. Vertical bars indicate one standard error. Treatment means in each year followed by different letters differ significantly at $p \leq 0.1$ for log transformed data. No letters are included for years without significant differences.

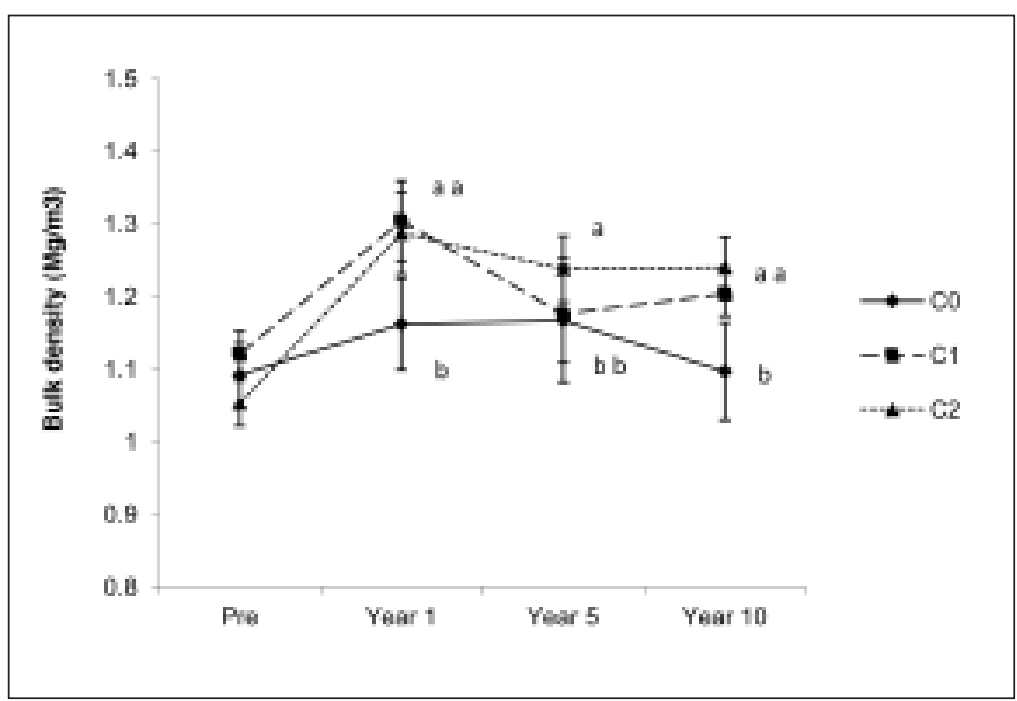

Fig. 2. Upper $(0-10 \mathrm{~cm})$ mineral soil bulk density by compaction treatment (CO, no compaction; C1, intermediate compaction; C2 heavy compaction). Vertical bars indicate one standard error. Treatment means in each year followed by different letters differ significantly at $p \leq 0.1$ for log transformed data. No letters are included for years without significant differences.

intermediate and heavy compaction treatments were $7.4 \%$ and $17.8 \%$ greater, respectively.

Interactions between organic matter removal and soil compaction were not significant for any of the regeneration variables analyzed up to Year 10. Results for the main effects of organic matter removal and soil compaction are therefore discussed separately.

Initial aspen regeneration was high for all treatments, with the forest floor + whole tree removal having 192000 stems per ha (Fig. 3). After 10 growing seasons the forest floor + whole tree removal aspen density (31 634 stems per ha) was 


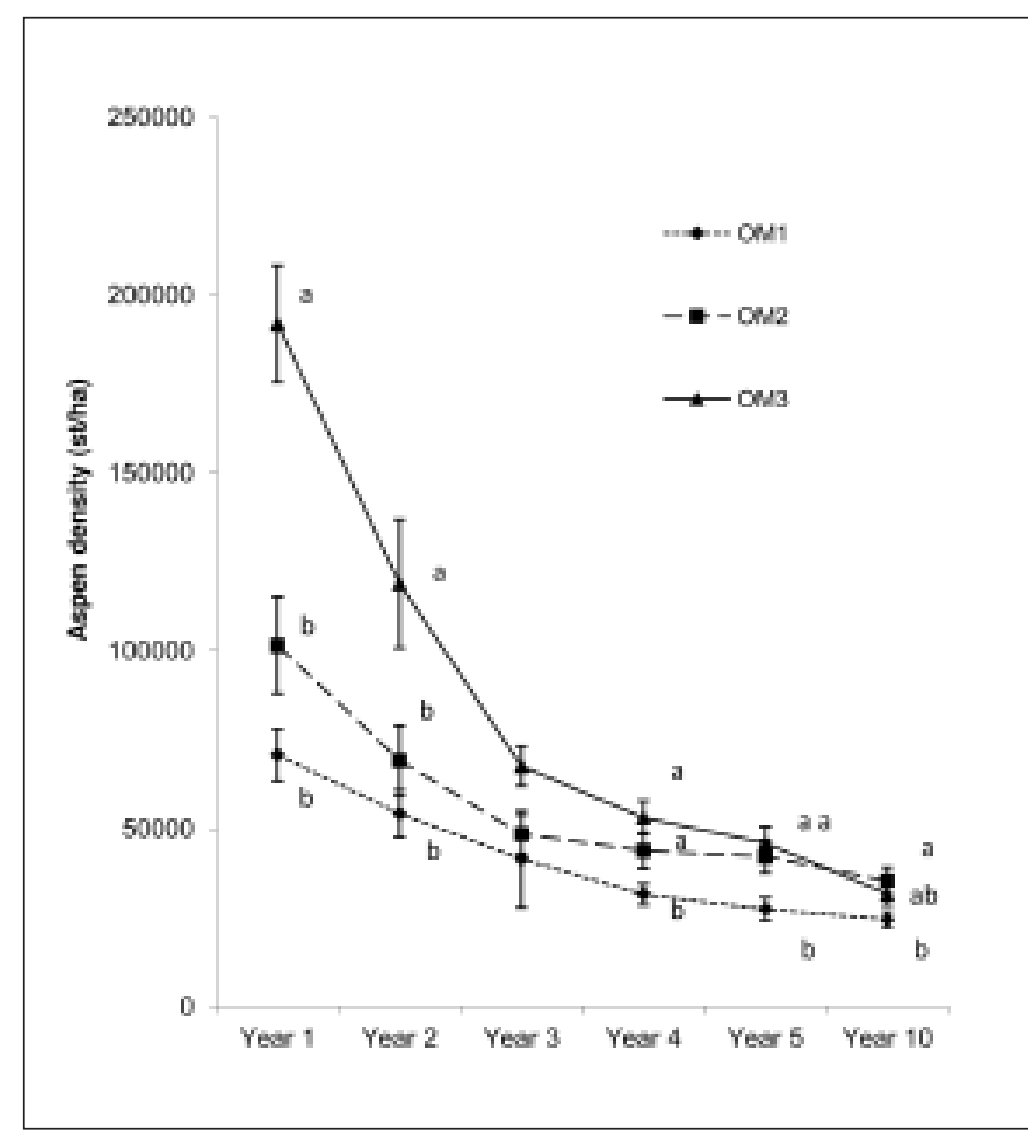

Fig. 3. Aspen regeneration density by organic matter removal treatment (OM1, stems only; OM2, stems and slash; OM3, stems, slash and forest floor]. Vertical bars indicate one standard error. Treatment means in each year followed by different letters differ significantly at $p<0.1$. No letters are included for years without significant differences.

not significantly different from the other two treatments (Fig. 3). The stem and slash removal (35 356 stems per ha) had significantly higher aspen density than the stem-only removal treatment (24 304 stems per ha). The standard error of the mean was similar between treatments (Table 2), indicating that variation in aspen distribution was similar between treatments. Between Years 5 and 10, aspen mortality was greatest with forest floor + whole tree removal, with stem density declining $31 \%$, compared to $11 \%$ and $16 \%$ for the stem only, and stem and slash removal treatments, respectively.

Aspen height growth was even more strongly affected by forest floor removal. Height of aspen dominants in the forest floor + whole tree removal treatment averaged $198 \mathrm{~cm}$ in Year 10 , which was significantly less $(p<0.001)$ than the average heights of $480 \mathrm{~cm}$ for stem only and $472 \mathrm{~cm}$ for stem and slash removal.

Aspen stem density was not significantly $(p<0.451)$ affected by soil compaction treatments at Year 10, ranging from 28889 to 32237 stems per ha. Year 10 heights of aspen dominants were $364 \mathrm{~cm}$ for the intermediate and $321 \mathrm{~cm}$ for the heavy compaction treatments, which were significantly ( $p$ $<0.008$ ) shorter than those of the uncompacted soil at $465 \mathrm{~cm}$ (Fig. 4). Heights of aspen dominants on uncompacted soils were significantly greater than aspen on compacted soils beginning in Year 4 (Fig. 4). Average aspen height had the same relationship as aspen dominant height for the compaction treatments from Year 4 to Year 10 (data not shown).

Aspen site index (age 50 years at $1.3 \mathrm{~m}$, Nigh et al. 2002) was $9 \mathrm{~m}$ for the forest floor + whole tree removal treatment, $20 \mathrm{~m}$ for the stem and slash removal and $21 \mathrm{~m}$ for the stem only removal (Table 2). The uncompacted soils had a predicted aspen site index of $19 \mathrm{~m}$, while the intermediate and heavy compaction treatments had predicted site indices of $17 \mathrm{~m}$ and $14 \mathrm{~m}$, respectively (Table 2).

The best combined model to predict aspen dominant height at 10 years after harvest was a multiple regression equation $\left(\mathrm{r}^{2}=0.829, p<\right.$ 0.001 ) that included Year 10 upper mineral soil bulk density, Year 10 Calamagrostis cover, and removal of the forest floor (Table 3). Upper mineral soil bulk density alone was a good predictor of aspen height $\left(\mathrm{r}^{2}=0.693, p<0.001\right.$, Table 3). Where the forest floor was retained, Calamagrostis cover in Year 10 had a significant negative relationship with aspen height growth $\left(\mathrm{r}^{2}=0.383, p<0.004\right.$, Table 3). Both Calamagrostis cover and aspen height growth (Table 2) were reduced by the forest floor + whole tree removal treatment.

Average height of white spruce at Year 10 on the forest floor + whole tree removal treatment was $81.7 \mathrm{~cm}$, significantly less than the stem only and stem plus slash treatments, which were $154.2 \mathrm{~cm}$ and $156.2 \mathrm{~cm}$ in height, respectively (Fig. 5). White spruce height increment and basal diameter had the same relationship between the treatments, where stem only and stem plus slash were not significantly different from each other, but were significantly greater than the forest floor + whole tree removal treatment (data not shown). The compaction treatment effect on spruce height growth was not significant $(p<0.190)$ in a repeated measures ANOVA. There was no significant difference between the intermediate and heavy compaction treatments for white spruce height in Years $4(p<0.540), 5(p<0.849)$ and $10(p<0.974)$. However, a planned contrast for no compaction versus pooled intermediate and heavy compaction treatments was significant for white spruce height in Years $4(p<0.057), 5(p<0.076)$ and $10(p<0.065)$. Mean 10-year height of spruce in uncompacted soils was $151 \mathrm{~cm}$, compared to $119 \mathrm{~cm}$ and $122 \mathrm{~cm}$ for the intermediate and heavy compaction treatments, respectively.

Total height to ground diameter ratio for the forest floor + whole tree removal treatment at Year 10 (42) was significantly lower than stem only (55) $(p<0.001)$ and stem plus slash (54) $(p<0.001)$. There was no difference between stem only and stem plus slash $(p<0.520)$ treatments in Year 10. Year of harvest was a significant covariate $(p<0.001)$ for this analysis.

Upper mineral soil bulk density at Year 10 was the best single predictor of white spruce total height at Year $10\left(\mathrm{r}^{2}=\right.$ $0.501, p<0.001$, Table 3). A two factor model with the upper mineral soil bulk density and a forest floor removal dummy variable $\left(\mathrm{r}^{2}=0.581, p<0.001\right.$, Table 3$)$ was the best predictor 
Table 2. Summary of effects of organic matter (OM) removal and soil compaction (C) for selected soil, tree and vegetation properties in Year 10

\begin{tabular}{|c|c|c|c|c|c|c|c|}
\hline \multicolumn{8}{|c|}{ Property } \\
\hline \multirow[b]{2}{*}{ Treatment } & \multirow[b]{2}{*}{$\begin{array}{l}\text { Mean } 0-2 \mathrm{~cm} \\
\text { aeration porosity } \\
\quad\left(\mathrm{m}^{3} \mathrm{~m}^{-3}\right)\end{array}$} & \multirow{2}{*}{$\begin{array}{l}\text { Mean and } \\
\text { standard error } \\
\text { (below) for } \\
\text { aspen density } \\
\text { (stems per ha) }\end{array}$} & \multirow{2}{*}{$\begin{array}{l}\text { Mean aspen } \\
\text { dominant } \\
\text { height }(\mathrm{cm})\end{array}$} & \multirow[b]{2}{*}{$\begin{array}{c}\text { Aspen site } \\
\text { index (m @ } \\
50 \text { years) }\end{array}$} & \multirow{2}{*}{$\begin{array}{l}\text { White spruce } \\
\text { height to } \\
\text { ground } \\
\text { diameter ratio }\end{array}$} & \multicolumn{2}{|c|}{$\begin{array}{c}\text { Mean Calamagrostis } \\
\text { cover }(\%)\end{array}$} \\
\hline & & & & & & $\begin{array}{l}\text { Aspen } \\
\text { subplots }\end{array}$ & $\begin{array}{l}\text { Spruce } \\
\text { subplots }\end{array}$ \\
\hline \multirow[t]{2}{*}{ OM1 } & 15.8 & 24304 & 480.3 & 22 & 55 & 27.9 & 33.3 \\
\hline & - & (2 178) & - & - & - & - & - \\
\hline \multirow[t]{2}{*}{ OM2 } & 20.1 & 35356 & 471.9 & 21 & 54 & 34.0 & 39.4 \\
\hline & - & $(3684)$ & - & - & - & - & - \\
\hline \multirow[t]{2}{*}{ OM3 } & 14.4 & 31637 & 197.7 & 9 & 42 & 7.7 & 8.9 \\
\hline & - & (3 207) & - & - & - & - & - \\
\hline \multirow[t]{2}{*}{$\mathrm{C} 0$} & 16.6 & 28889 & 465.0 & 21 & 52 & 17.4 & 17.0 \\
\hline & - & (2 973) & - & - & - & - & - \\
\hline \multirow[t]{2}{*}{$\mathrm{C} 1$} & 18.0 & 30170 & 363.8 & 16 & 50 & 30.1 & 33.0 \\
\hline & - & (3963) & - & - & - & - & - \\
\hline \multirow[t]{2}{*}{$\mathrm{C} 2$} & 15.3 & 32237 & 321.1 & 15 & 49 & 22.2 & 31.7 \\
\hline & - & (3 354) & - & - & - & - & - \\
\hline
\end{tabular}

Note: OM1, stems only; OM2, stems and slash; OM3 stems, slash and forest floor; C0, no compaction; C1, moderate compaction; C2, heavy compaction. Aspen site index is for age 50 years at $1.3 \mathrm{~m}$, using Nigh et al. (2002).

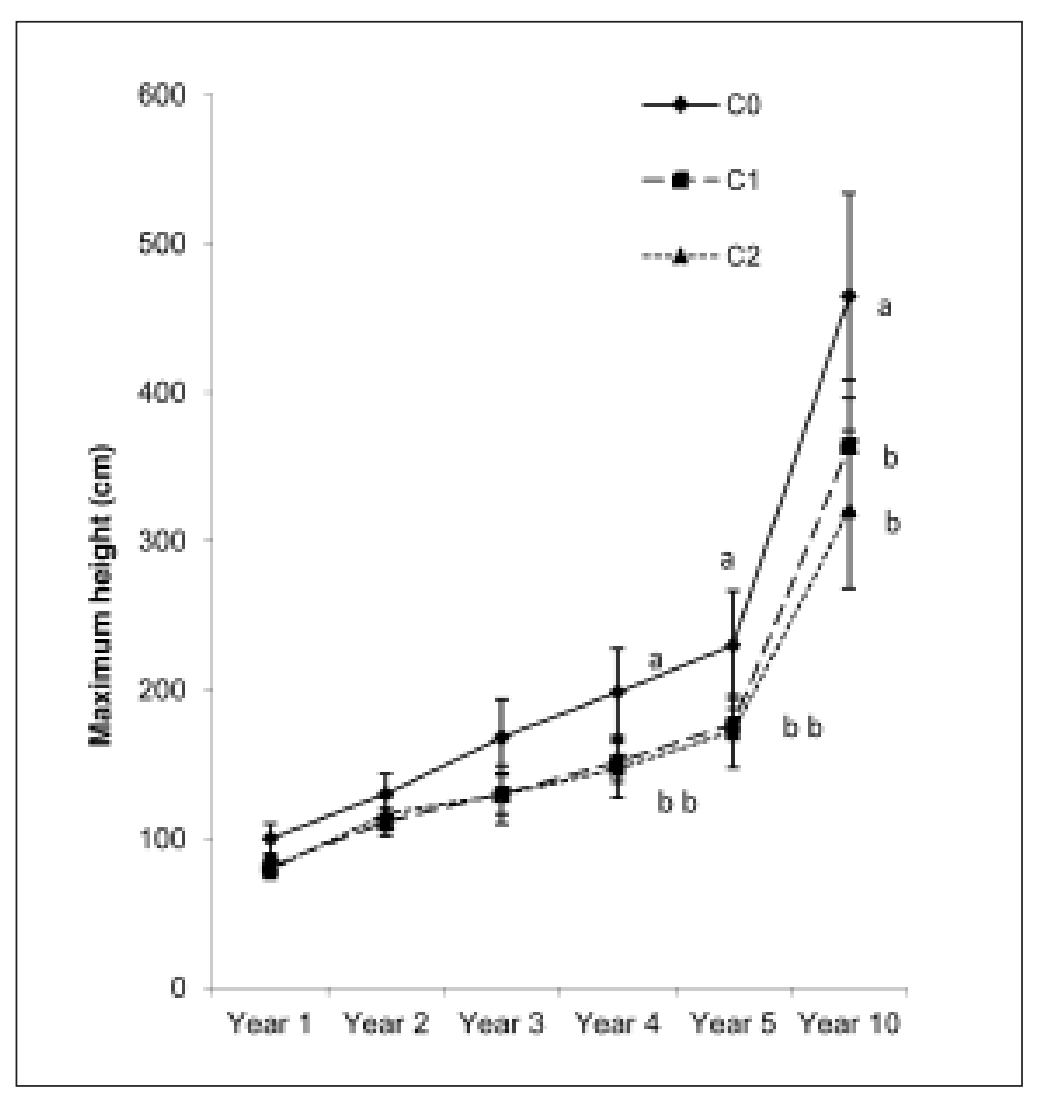

Fig. 4. Aspen dominant height by compaction treatment (CO, no compaction; C1, intermediate compaction; C2 heavy compaction]. Vertical bars indicate one standard error. Treatment means in each year followed by different letters differ significantly at $p \leq 0.1$. No letters are included for years without significant differences. of Year 10 white spruce height. The pre-harvest to post-treatment change in upper mineral soil bulk density was a moderate predictor $\left(\mathrm{r}^{2}=\right.$ $0.373, p<0.001$, Table 3) of Year 10 white spruce height. Where forest floor was retained, Calamagrostis cover was a weak but statistically significant predictor of white spruce height at Year $10,\left(\mathrm{r}^{2}=0.12, p<0.087\right.$, Table 3$)$. Three and four factor models that combined upper mineral soil bulk density, forest floor removal, changes in upper mineral soil bulk density, and Calamagrostis cover did not have greater predictive ability than the two factor model.

\section{Discussion}

\section{Recovery of soil properties}

The timing of recovery of soil properties from soil disturbance varies with factors such as the original degree of disturbance ( $\mathrm{McNabb}$ et al. 2001), climate (Page-Dumroese et al. 2006), soil texture (Steber et al. 2007), organic matter content (Krzic et al. 2004), and depth being considered (Zenner et al. 2007). Upper mineral soil bulk density at this site was still significantly greater on the compaction treatments after 10 years, similar to the 10 -year results of the LTSP network (Powers et al. 2005), the 11 years of Puettmann et al. (2008) and 12 years of Shepperd (1993), but in contrast to the return to pre-disturbance bulk density within 10 years documented by Bockheim et al. (2005). At Minnesota aspen sites, the loam textured soils 
Table 3. Summary of predictive relationships for aspen dominant height at year 10, white spruce total height at Year 10 with soil and vegetation properties

\begin{tabular}{|c|c|c|c|c|}
\hline Variable & Predictive model & $\mathbf{n}$ & $\mathbf{r}_{\text {ajd }}^{2}$ & $p$ \\
\hline Aspen dominant height Year $10(\mathrm{~cm})$ & $\begin{array}{l}\mathrm{Y}=1505-1115 \mathrm{LUBD}-37.5 \mathrm{CC} \%-265 \mathrm{OM} 3 \\
\mathrm{Y}=1958-2027 \mathrm{LUBD} \\
\mathrm{Y}=472.829-668 \mathrm{~L} \Delta \mathrm{BD}\end{array}$ & $\begin{array}{l}27 \\
27 \\
27\end{array}$ & $\begin{array}{l}0.829 \\
0.693 \\
0.478\end{array}$ & $\begin{array}{l}<0.001 \\
<0.001 \\
<0.001\end{array}$ \\
\hline $\begin{array}{l}\text { Aspen dominant height Year } 10(\mathrm{~cm}) \text { where } \\
\text { forest floor was retained }(\mathrm{OM} 1, \mathrm{OM} 2)\end{array}$ & $\mathrm{Y}=772-55 \mathrm{CC} \%$ & 18 & 0.383 & $<0.004$ \\
\hline $\begin{array}{l}\text { White spruce total height Year 10, } \\
\text { square root transformation }\end{array}$ & $\begin{array}{l}\mathrm{Y}=29.9-22.8 \mathrm{LUBD} \\
\mathrm{Y}=22.6-13.9 \mathrm{LUBD}-2 \mathrm{OM} 3 \\
\mathrm{Y}=12.3-7.8 \mathrm{~L} \Delta \mathrm{BD} \\
\mathrm{Y}=22.4-10.9 \mathrm{LUBD}-0.9 \mathrm{~L} \Delta \mathrm{BD}-0.3 \mathrm{CC} \%-3 \mathrm{OM} 3\end{array}$ & $\begin{array}{l}27 \\
27 \\
27 \\
27\end{array}$ & $\begin{array}{l}0.501 \\
0.581 \\
0.373 \\
0.590\end{array}$ & $\begin{array}{l}<0.001 \\
<0.001 \\
<0.001 \\
<0.001\end{array}$ \\
\hline $\begin{array}{l}\text { White spruce total height Year 10, } \\
\text { square root transformation, where forest } \\
\text { floor was retained (OM1, OM2) }\end{array}$ & $Y=15.1-0.473 C C \%$ & 18 & 0.120 & $<0.087$ \\
\hline
\end{tabular}

Note: $\mathrm{LUBD}=\log$ transformation of upper mineral soil bulk density year 10; CC\% = square root transformation of $\%$ Calamagrostis cover at Year 10; OM3= removal of the forest floor, dummy variable; $\mathrm{L} \Delta \mathrm{BD}=\log$ transformation of pre- to post-treatment change in upper mineral soil bulk density.

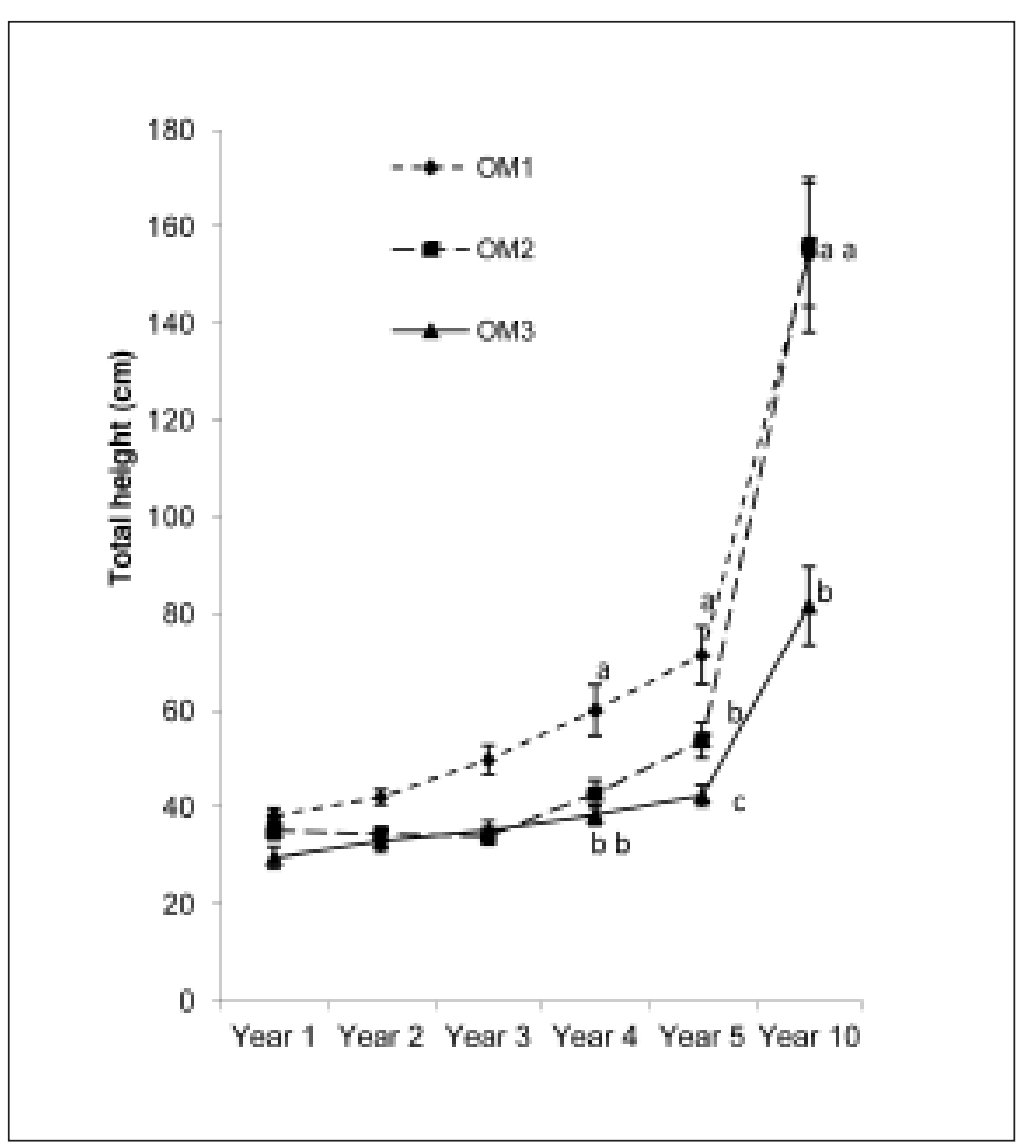

Fig. 5. White spruce total height by organic matter removal treatment (OM1, stems only; OM2, stems and slash; OM3, stems, slash, and forest floor]. Vertical bars indicate one standard error. Treatment means in each year followed by different letters differ significantly at $p \leq 0.1$ for square root transformed data. No letters are included for years without significant differences.

had $17 \%$ to $19 \%$ increases in bulk density after compaction (Page-Dumroese et al. 2006), which were very comparable to the $16 \%$ to $22 \%$ increases at this site. At this study site, there was no significant difference for upper mineral soil bulk density between the moderate and severe compaction treatments, similar to other LTSP sites (Powers et al. 2005, Page-Dumroese et al. 2006). Three years after harvest, the $0 \mathrm{~cm}$ to $5 \mathrm{~cm}$ layer of mineral soil had full recovery to pre-harvest conditions measured by soil penetrometer resistance on Minnesota aspen sites where four or fewer machine passes had occurred (Zenner et al. 2007), which is more rapid than the five- to 10 -year recovery for aeration porosity of the $0 \mathrm{~cm}$ to $2 \mathrm{~cm}$ layer at this site. The $10 \mathrm{~cm}$ to $15 \mathrm{~cm}$ layer in mineral soil did not show recovery from soil compaction within three years on the Minnesota aspen sites studied by Zenner et al. (2007). The slowest rates of recovery from heavy compaction treatments after 10 years were present in boreal and cool temperate climates within the LTSP network (Powers et al. 2005).

The soil properties of total $\mathrm{C}$ concentration (Table 1) and bulk density (Fig. 1) indicated a partial recovery from forest floor removal over the first ten years. Upper mineral soil total C concentrations increased between years 1 and 10 on the forest floor + whole tree removal treatment (Table 1), while still remaining below preharvest total $\mathrm{C}$ concentrations, consistent with other LTSP sites (Powers et al. 2005). Organic matter inputs and biological activity related to forest successional patterns would explain the lack of differences in aeration porosity values at Year 10 between organic matter removal treatments for the $0 \mathrm{~cm}$ to $2 \mathrm{~cm}$ mineral soil horizon (Table 2). Where the forest floor was retained, the increased organic matter inputs in intermediate and heavy compaction treatments was dominated by fine root material and litter from the expansion of Calamagrostis canadensis cover (Haeussler and Kabzems 2005). 
The use of relative bulk density can provide a quantitative comparison of compaction over a range of soil textures (Krzic et al. 2004). Relative bulk density is the ratio of soil bulk density to a reference density (Hakansson and Lipiec 2000), often a maximum bulk density value determined by a Proctor test (ASTM n.d.). Using the maximum bulk density value of 1.40 $\mathrm{Mg} \mathrm{m}^{-3}$ for the study site from Krzic et al. (2004), even the uncompacted treatment had a relative bulk density value over 0.8 . Such a high value demonstrates that compaction of the mineral soil is a management concern on this site, as a small change would increase the relative bulk density into the range where growth reductions have been documented (Bulmer and Simpson 2010). The intermediate and heavy compaction treatments increased relative bulk density values in Year 1 to over 0.9 , well within the high level of relative bulk density values where growth reduction in conifer seedlings occurs (Bulmer and Simpson 2010). At Year 10, upper mineral soil relative bulk density values were above 0.86 , still in the "high" compaction range where growth reductions of conifer seedlings can be expected.

The scraping action of the excavator bucket used to remove the forest floor also increased mineral soil bulk density, and relative bulk density values were over 0.9 from Year 1 to Year 10. The upper mineral soil bulk density of the forest floor + whole tree removal treatments declined $7.5 \%$ from Year 1 to Year 10, but Year 10 values were still 26\% greater than pre-harvest bulk density values. Recovery of soil properties on this treatment will involve both the reestablishment of the forest floor and the suite of factors that decrease upper mineral soil bulk density in forest ecosystems.

\section{Tree growth responses}

Forest floor removal had a dramatic effect on aspen suckering rates and on 10-year growth of both aspen and white spruce. Aspen regeneration density was initially stimulated by removal of the forest floor (Fig. 3), most likely due to the positive effects of increased soil temperature (Peterson and Peterson 1992) and slightly wounding aspen roots (Fraser et al. 2004). The mortality of aspen suckers was so rapid that within 10 years the density of aspen regeneration was not significantly different from that of treatments that had retained the forest floor. The initial stimulation and rapid mortality of aspen is consistent with responses for aspen LTSP sites in the United States (Powers et al. 2005), but were in contrast to the results of Bockheim et al. (2005) where forest floor removal did not have a reduction in aspen stocking or height growth more than two years after treatment. Aspen biomass at Year 10 was reduced by forest floor + whole tree removal at the LTSP sites in the United States (Powers et al. 2005). Where forest floor was retained, the trends in aspen density on this site were similar to four long-term experimental locations in western Canada, which averaged 73888 stems per ha in the first growing season and declined to 22782 stems per ha in Year 9 (Bokalo et al. 2007). The levels of woody debris retention found on this site had incomplete coverage of treatment plots and did not form a dense mat or compacted layer. Woody debris retention alone did not appear to be a factor that could create significant differences in aspen density by effects on soil warming (Bella 1986) or by creating a physical barrier to sucker emergence (Landhäusser et al. 2007). For aspen height growth at this site, effects of organic matter removal and compaction were both significant and independent from each other in contrast to Bockheim et al. (2005), where forest floor removal alone did not have a significant effect on aspen height.

The effects of retaining different amounts of organic material in addition to the forest floor had negligible effects on white spruce growth at Year 10, consistent with overall LTSP conifer regeneration results (Fleming et al. 2006). The lack of statistical difference between the stem and slash removal treatment and forest floor + whole tree removal during the first four years of the study (Fig. 5) was due to winter desiccation damaging the upper portion of the spruce stems (Kabzems and Haeussler 2005). These initial differences of 10 $\mathrm{cm}$ to $20 \mathrm{~cm}$ between the treatments disappeared by Year 10 when total heights were over $150 \mathrm{~cm}$.

Soil compaction reduces root respiration and growth through the combined effects of reduced aeration and impeded drainage (Ruark et al. 1982). For aspen, other effects of soil disturbance such as injuries to root systems may better explain regeneration response than compaction alone (Zenner et al. 2007). Aspen regeneration numbers were high for all treatments in this study, which does not support the idea that Year 10 growth responses reflect initial damage to the parent root system. Rapid mortality of aspen with forest floor removal, and significantly lower height growth of aspen and spruce on compaction treatments suggests that changes in soil conditions best explain plant growth responses on this site.

Compaction did not result in reduced aspen regeneration density in this study, in contrast to reductions in density found under operational conditions (Shepperd 1993, Navratil 1996, Kabzems 1996, Berger et al. 2004, Zenner et al. 2007, Puettmann et al. 2008). This can be attributed to a combination of the degree and timing of the compaction treatments applied compared to operational harvests. The $16 \%$ to $22 \%$ increases in mineral soil bulk density were less than the $22 \%$ to $34 \%$ increases reported under operational conditions (Kabzems 1996). The decreased sucker production on aspen LTSP sites in Minnesota was attributed to late spring application of compaction treatments in Minnesota compared to this site, where treatments were applied several weeks prior to aspen sucker emergence (Stone and Kabzems 2002). Differences in aspen regeneration attributed to winter versus summer harvest may actually reflect differences in degree of harvest disturbance (Mundell et al. 2008).

Compacted soil can reduce conifer seedling growth by restrictions to root growth, root extension and density (Corns 1988, Kozlowski 1999). As an overall trend within the LTSP studies, a moderate level of soil compaction combined with intact forest floors benefited both growth and survival of conifers (Fleming et al. 2006, Tan et al. 2009). Bulmer and Simpson (2010) demonstrated that conifer seedling growth can be negatively affected by compaction, but that available water content is important for determining the degree of variation in growth responses. The significant regression for mineral soil bulk density with spruce height observed in this study indicates that even where the forest floor was retained, growth of spruce seedlings was affected by mineral soil conditions. The importance of mineral soil conditions may 
become more apparent on the conifer root systems in the future as they continue to expand and exploit the soil environment. The lateral root system of aspen occupied the entire available soil volume on a plot when the treatments were applied, which may explain the stronger relationship between aspen growth and soil conditions after 10 years. In addition to spruce root systems not fully occupying soil at Year 10, the ability for spruce to root in lower portions of the forest floor would also contribute to the relatively weaker relationship between spruce growth and soil conditions.

The change in soil conditions created by compaction initiated and enabled Calamagrostis dominance of the post harvest plant community (Haeussler and Kabzems 2005). A combination of interspecies competition, in addition to the reduced rates of $\mathrm{N}$ cycling and $\mathrm{N}$ availability associated with Calamagrostis litter (Landhäusser and Lieffers 1998; Matsushima and Chang 2006, 2007) would further reduce growth of aspen and white spruce where soils had been compacted. Calamagrostis cover had a stronger negative effect on aspen height growth compared to white spruce, probably due to the repeated manual brushing of spruce carried out for the first five years of the study.

The repeated (first 5 years) manual brushing applied for a 1- $\mathrm{m}$ radius around individual spruce trees achieved the objective of reducing the effects of light competition on the spruce (Pitt et al. 2010), so that growth response would reflect soil conditions rather than the surrounding plant community. Spruce height to diameter ratio has a significant response to aspen density, and is 50 and lower when aspen density is below 500 stems per ha (Bokalo et al. 2007). Height to ground level diameter ratios of the spruce ranged from 55 (stem only) to 42 (forest floor + whole tree removal) at Year 10, consistent with low levels of competition.

Disturbances similar to the experimental treatments used in this study can be extensive within operational harvesting areas. The forest floor removal combined with compaction would be most similar to roads within operational cutblocks, ranging from $3 \%$ to $5 \%$ of the cutblock area (Block et al. 2002, MacIsaac et al. 2006). Adjacent to roads, repeated machine traffic areas used for processing and loading of logs, but where forest floor would not be removed, can occupy from $4 \%$ to $5 \%$ (Macisaac et al. 2006) up to $10 \%$ to $20 \%$ (British Columbia Ministry of Forests, unpublished data) of the harvested area. When all sources of harvesting disturbance are combined, up to $32 \%$ of a harvested opening can have bulk density increases greater than 15\% (Block et al. 2002).

Puettmann et al. (2008) used the assumptions that aspen height was only affected in absolute terms for the first 10 years or that the relative height difference was present at the end of the rotation to demonstrate "best case" and "worst case" scenarios. A $9 \%$ yield reduction was estimated with $20 \%$ of the harvest area in skid trails, in the worst case scenario where growth was affected through the 50 -year rotation. Bulk density increases are still present 10 years after harvest on this site, suggesting that aspen height growth will continue to be reduced for some time into the future. The reduction in aspen site index ranged from $11 \%$ to $26 \%$ for the intermediate and heavy compaction treatments, which would also support the "worst case" scenario.

\section{Conclusions}

Both aspen and white spruce had significant responses to organic matter removal and soil compaction. Forest floor removal was the most disruptive disturbance, significantly reducing aspen height by the second year, and spruce height by the fifth year. The effects of soil compaction became statistically significant by the fourth year for both species. Upper mineral soil bulk density was the variable that had the most predictive ability for 10-year height of both aspen and white spruce. Mineral soil bulk density may be a proxy for a number of soil properties (macroporosity, drainage) and linked to other variables such as Calamagrostis cover, which all contribute to reduced growth of aspen and white spruce. There was evidence for some degree of recovery of soil porosity and carbon content in the upper mineral soil to pre-harvest conditions. Upper mineral soil bulk density, which had the best relationship to height growth of both aspen and white spruce, was still in the range where reduced growth rates could be expected 10 years after harvest. These results support existing guidelines for planning harvest block layout to minimize area in roads and landings and for machine operation to prevent negative soil disturbance to sustain long-term productivity of boreal forests.

\section{Acknowledgements}

Funding for the Long Term Soil Productivity study has been provided by Forest Renewal BC and the Forest Investment Account. Ralph Crick Logging, Randy Miller and Clint Fredrickson carried out harvesting and experimental treatments with care and attention. Soil analyses were conducted by Clive Dawson and staff at the Glyn Road laboratory. Thanks also to the many student assistants and British Columbia Ministry of Forests soil scientists who have assisted with this study over the years. The constructive comments made by Graeme Hope, Shannon Berch, Paul Sanborn and two anonymous reviewers on earlier versions of this manuscript are appreciated.

\section{References}

Arnup, R. 2000. Minimizing Soil Disturbance in Forestry Operations: A Practical Field Guide for Resource Managers and Equipment Operators in Northeastern Ontario. The Lake Abitibi Model Forest, Cochrane, Ontario. 26 p.

ASTM. n.d. ASTM Standard D698 - 07e1. Standard Test Methods for Laboratory Compaction Characteristics of Soil Using Standard Effort $\left.\left(12,400 \mathrm{ft}-\mathrm{lbf} / \mathrm{ft}^{3}\right) 600 \mathrm{kN}-\mathrm{m} / \mathrm{m}^{3}\right)$ ) [online]. ASTM International, West Conshohocken, PA. Available from http:// www.astm.org/Standards/D698.htm. DOI: 10.1520/D0698-07E01.

Bates, P.C., C.R. Blinn and A.A. Alm. 1990. A survey of the harvesting histories of some poorly regenerated aspen stands in northern Minnesota. In R.D. Adams (ed.). Aspen Symposium '89. Proc. Symp. July 25-27, 1989, Duluth, MN. pp. 221-230. U.S. Dept. Agric. Forest Service, Gen. Tech. Rep. NC-140, North Central Forest Exp. Station.

Beckingham, J.D., D.G. Nielsen, and V.A. Futoransky. 1996. Field guide to ecosites of the mid-boreal ecoregions of Saskatchewan. Nat. Resour. Can., Can. For. Serv., Northwest Reg., North. For. Cent., Edmonton, AB. Spec. Rep. 6.

Bella, I.E. 1986. Logging practices and subsequent development of aspen stands in east-central Saskatchewan. For. Chron. 62: 81-83. 
Berger, A.L., K.J. Puettmann and G.E. Host. 2004. Harvesting impacts on soil and understory vegetation: the influence of season of harvest and within-site disturbance patterns on clear-cut aspen stands in Minnesota. Can. J. For. Res. 34: 2159-2168.

Blake, G.R. and K.H. Hartge. 1986. Bulk density. In A. Klute (ed.). Methods of soil analysis. Part 1. Physical and mineralogical methods. 2nd ed. Agronomy 9(1): 363-375.

Block, R., K.C.J. Van Rees and D.J. Pennock. 2002. Quantifying harvesting impacts using soil compaction and disturbance regimes at a landscape scale. Soil Sci. Soc. Am. J. 66: 1669-1676.

Boateng, J.O., J. L. Heineman, L. Bedford, G.J. Harper and A.F.L. Nemec. 2009. Long-term effects of site preparation and postplanting vegetation control on Picea glauca survival, growth and predicted yield in boreal British Columbia. Scan. J. For. Res. 24: 111-129.

Bockheim, J.G., H. Park and J. Gallagher. 2005. Genotypic variation and recovery of Populus tremuloides from biomass removal and compaction in northern Wisconsin, USA. Can. J. For. Res. 35: 221-228.

Bokalo, M., P.G. Comeau and S.J. Titus. 2007. Early development of tended mixtures of aspen and spruce in western Canadian boreal forests. For. Ecol. Manage. 242: 175-184.

Brais, S. 2001. Persistence of soil compaction and effects on seedling growth in northwestern Quebec. Soil. Sci. Soc. Am. J. 65: 1263-1271. Bulmer, C.E. and D.G. Simpson. 2010. Soil compaction reduced the growth of lodgepole pine and Douglas-fir seedlings in raised beds after two growing seasons. Soil Sci. Soc. Am. J. 74(6): 2162-2174.

Campbell, G.S. 1974. A simple method for determining unsaturated conductivity from moisture retention data. Soil Sci. 117: 311-314.

Corns, I.G.W. 1988. Compaction by forestry equipment and effects on coniferous seedling growth on four soils in the Alberta foothills. Can. J. For. Res. 18: 75-84.

David, A.J., J.C. Zasada, D.W. Gilmore and S.M. Landhäusser. 2001. Current trends in the management of aspen and mixed aspen forest for sustainable production. For. Chron. 77: 525-532.

Delong, C., A. Banner, W.H. MacKenzie, B.J. Rogers and B. Kaytor. 2011. A field guide to ecosystem identification for the Boreal White and Black Spruce Zone of British Columbia. B.C. Min. For. Range, For Sci. Prog., Victoria, B.C. Land Manage. Handb. No. 65. Fleming, R.L. et al. 2006. Effects of organic matter removal, soil compaction, and vegetation control on 5-year seedling performance: a regional comparison of Long-Term Soil Productivity sites. Can. J. For. Res. 36: 529-550.

Fraser, E.C., V.J. Lieffers and S.M. Landhäusser. 2004. Wounding of aspen roots promotes suckering. Can. J. Bot. 82: 310-315.

Frey, B.R., V.J Lieffers, S.M. Landhäusser, P.G. Comeau and K.J. Greenway. 2003. An analysis of sucker regeneration of trembling aspen. Can. J. For. Res. 33: 1169-1179.

Haeussler, S. and R. Kabzems. 2005. Aspen plant community response to organic matter removal and soil compaction. Can. J. For. Res. 35: 2030-2044.

Hakansson, I. and J. Lipiec. 2000. A review of the usefulness of relative bulk density values in studies of soil structure and compaction. Soil Tillage Res. 53: 71-85.

Kabzems, R. 1996. Where have all the big pores gone? Impacts of concentrated heavy equipment traffic on aeration porosity and bulk density in an aspen ecosystem. In P.G. Comeau, G.J. Harper, M.E. Blache, J.O. Boateng and K.D. Thomas (eds.). Ecology and management of B.C. hardwoods. Workshop Proc. Dec. 1-2, 1993. Richmond, BC. pp. 209-210. BC Ministry of Forests and Forestry Canada, Canada-British Columbia Partnership Agreement on Forest Resource Development, FRDA Rep. 255.

Kabzems, R. and S. Haeussler. 2005. Soil properties, aspen, and white spruce responses 5 years after organic matter removal and compaction treatments. Can. J. For. Res. 35: 2045-2055.
Klute, A. 1986. Water retention: laboratory methods. In A. Klute (ed.). Methods of soil analysis. Part 1. Physical and mineralogical methods. 2nd ed. Agronomy 9(1): 687-734.

Kozlowski, T.T. 1999. Soil compaction and growth of woody plants. Scand. J. For. Res. 14: 596-619.

Krzic, M., C.E. Bulmer, F. Teste, L. Dampier and S. Rahman. 2004. Soil properties influencing compactability of forest soils in British Columbia. Can. J. Soil Sci. 84: 219-226.

Landhäusser, S.M. and V.J. Lieffers. 1998. Growth of Populus tremuloides in association with Calamagrostis canadensis. Can. J. For. Res. 28: 396-401.

Landhäusser, S.M., V.J. Lieffers and P. Chow. 2007. Impact of chipping residues and their leachate on the initiation and growth of aspen root suckers. Can. J. Soil Sci. 87: 361-367.

Macadam, A. and R. Kabzems. 2006. Vegetation management improves early growth of white spruce more than mechanical site preparation treatments. North. J. App. For. 23(1): 35-46.

MacIsaac, D.A., P.G. Comeau and S.E. Macdonald. 2006. Dynamics of regeneration gaps following harvest of aspen stands. Can. J. For. Res. 36: 1818-183.

Matsushima, M. and S.X. Chang. 2006. Vector analysis of understory competition, $\mathrm{N}$ fertilization and litter layer removal effects on white spruce growth and nutrition in a 13-year-old plantation. For. Ecol. Manage. 236: 332-341.

Matsushima, M. and S.X. Chang. 2007. Effects of understory removal, $\mathrm{N}$ fertilization, and litter layer removal on soil $\mathrm{N}$ cycling in a 13-year-old white spruce plantation infested with Canada bluejoint grass. Plant Soil 292: 243-258.

McNabb, D.H., A.D. Startsev and H. Nguyen. 2001. Soil wetness and traffic level effects on bulk density and air-filled porosity of compacted forest soils. Soil Sci. Soc. Am. J. 65: 1238-1247.

Mundell, T.L., S.M. Landhäusser and V.J. Lieffers. 2008. Root carbohydrates and aspen regeneration in relation to season of harvest and machine traffic. For. Ecol. Manage. 255: 68-74.

Navratil, S. 1996. Sustained aspen productivity on hardwood and mixedwood sites. In P.G. Comeau, G.J. Harper, M.E. Blache, J.O. Boateng and K.D. Thomas (eds.). Ecology and management of B.C. hardwoods. Workshop Proc. Dec. 1-2, 1993. Richmond, BC. pp. 53-64. BC Ministry of Forests and Forestry Canada, Canada-British Columbia Partnership Agreement on Forest Resource Development, FRDA Rep. 255.

Neter J., W. Wasserman and M.H. Kutner. 1983. Applied linear regression models. Richard D. Irwin Inc., Homewood, IL.

Nigh, G.D., P.V. Krestov and K. Klinka. 2002. Trembling aspen height-age models for British Columbia. Northwest Science 76 (3): 202-212.

Page-Dumroese, D.S. et al. 2006. Soil physical property changes at the North American Long-Term Soil Productivity study sties: 1 and 5 years after compaction. Can. J. For. Res. 36: 551-564.

Peterson, E.B. and N.M. Peterson. 1992. Ecology, management, and use of aspen and balsam poplar in the prairie provinces. Forestry Canada, Northern Forestry Center, Edmonton. Special Report No. 1. Pitt, D.G., P.G. Comeau, W.C. Parker, D. MacIsaac, S. McPherson, M.K. Hoepting, A. Stinson and M. Mihajlovich. 2010. Early vegetation control for the regeneration of a single-cohort, intimate mixture of white spruce and trembling aspen on upland boreal sites. Can. J. For. Res. 40: 549-564.

Powers, R.F., D.H. Alban, R.E. Miller, A.E. Tiarks, C.G. Wells, P.E. Avers, R.G. Cline, R.O. Fitzgerald, N.S. Loftus Jr. 1990. Sustaining site productivity in North American forests: problems and prospects. In S.P. Gessel, D.S. Lacate, G.F. Weetman and R.F. Powers (eds.). Sustained productivity of forest soils. Proc. 7th North Amer. Forest Soils Conf. July 24-28, 1988. Vancouver, B.C., University of B.C., Faculty of Forestry. p. 49-79. 
Powers, R.F., D.A. Scott, F.G. Sanchez, R.A. Voldseth, D. PageDumroese, J.D. Elioff and D.M. Stone. 2005. The North American long-term soil productivity experiment: Findings from the first decade of research. For. Ecol. Manage. 220: 31-50.

Puettmann, K.J., A.W. D’Amato, M. Arikian and J.C. Zasada. 2008. Spatial impacts of soil disturbance and residual overstory on density and growth of regenerating aspen. Forest Ecol. Manage. 256: 2110-2120.

Ruark, G.A., D.L. Mader and T.A. Tattar. 1982. The influence of soil compaction and aeration on the root growth and vigor of trees a literature review. Part 1. Arboric. J. 6: 251-265.

Shepperd, W.D. 1993. The effects of harvesting activities on soil compaction, root damage and suckering in Colorado aspen. W. J. Appl. For. 8: 62-66.

Soil Classification Working Group. 1998. The Canadian System of Soil Classification, 3rd ed. Agriculture and Agri-Food Canada Publication $1646.187 \mathrm{p}$.

SPSS Inc. 2004. SYSTAT version 11 for Windows [computer program]. SPSS Inc., Chicago, IL.

Startsev, A.D. and D.H. McNabb. 2009. Effects of compaction on aeration and morphology of boreal forest soils in Alberta, Canada. Can. J. Soil Sci. 89: 45-56.

Steber, A., K. Brooks, C.H. Perry and R. Kolka. 2007. Surface compaction estimates and soil sensitivity in aspen stands of the Great Lakes States. North. J. Appl. For. 24(4): 276-281.
Stone, D.M. and J.D. Elioff. 1998. Soil properties and aspen development five years after compaction and forest floor removal. Can. J. Soil Sci. 78: 51-58.

Stone, D.M. and R. Kabzems. 2002. Aspen development on similar soils in Minnesota and British Columbia after compaction and forest floor removal. For. Chron. 87(6): 886-891.

Sutherland, B. 2003. Preventing Soil Compaction and Rutting in the Boreal Forest of Western Canada: A Practical Guide to Operating Timber-Harvesting Equipment. Forest Engineering Research Institute of Canada. Advantage Vol. 4, No. 7.52 p.

Tan, X., M. Curran, S. Chang and D. Maynard. 2009. Early growth responses of lodgepole pine and Douglas-fir to soil compaction, organic matter removal, and rehabilitation treatments in southeastern British Columbia. For. Sci. 55(3): 210-220.

Zasada, Z.A. and J.C. Tappeiner. 1969. Soil disturbance from rubber-tire skidders during summer harvesting of aspen. Univ. Minn. For. Res. Note 204. St. Paul, MN.

Zenner, E.K., J.T. Fauskee, A.L. Berger and K.J. Puettmann. 2007. Impacts of skidding traffic intensity on soil disturbance, soil recovery, and aspen regeneration in North Central Minnesota. North. J. Appl. For. 24(3): 177-183. 